\title{
Revendo o uso de dados do IBGE para pesquisa e planejamento territorial: reflexões quanto à classificação da situação urbana e rural
}

Reviewing the use of IBGE data for research and land planning: reflections on the classification of the urban and rural situation

Caroline Krobath Luz Pera Laura Machado de Mello Bueno

\section{Resumo}

Este artigo discute a classificação dos setores censitários, segundo sua situação urbana ou rural, propostos pelo Instituto Brasileiro de Geografia e Estatística. São exploradas as contribuições que esta classificação traz para o planejamento urbano, pontuando os limites e possibilidades da utilização desses dados para mapeamento da expansão urbana contemporânea e na estruturação do território além da dicotomia urbano-rural. Pontuou-se a necessidade dos usuários das informações censitárias conhecerem o método utilizado pelo Instituto para construção das bases cartográficas utilizadas durante a coleta, assim como refletir como dados do IBGE podem ser utilizados na construção de políticas públicas, destacando a relevância das informações coletadas e frisando o papel dos municípios em iniciativas para elaborar bases aprimoradas para melhores resultados no próximo censo.

Palavras-chave: variável "situação do setor censitário"; Instituto Brasileiro de Geografia e Estatística; dicotomia urbano-rural; planejamento da expansão urbana.

\begin{abstract}
This article discusses the classification of census tracts, according to their urban or rural situation, proposed by the Brazilian Institute of Geography and Statistics (IBGE). The contributions that this classification brings to urban planning are explored, and the limits and possibilities of the use of these data to map the contemporary urban expansion and to structure the territory beyond the urban-rural divide are emphasized. Users of census information should know the method used by the IBGE to construct cartographic databases utilized during collection. In addition, users should reflect on how IBGE data can be employed in the construction of public policies, highlighting the relevance of the collected information and stressing the role of municipalities in initiatives to develop improved databases in order to obtain better results in the next census.
\end{abstract}

Keywords: variable "census tract situation"; Brazilian Institute of Geography and Statistics; urban-rural divide; urban expansion planning. 


\section{Introdução'}

Há vasta bibliografia a respeito do que se considera urbano, rural, campo, cidade ou espaços além dessa dicotomia. Alguns autores empreendem discussões a partir de conceitos legais e político-administrativos. Outros estruturam suas discussões por meio de estudos analíticos da situação real encontrada no território, tendo como base o uso e a ocupação instaurados.

0 Instituto Brasileiro de Geografia e Estatística (IBGE), igualmente, possui uma definição sobre o que considera rural ou urbano. E essa definição, por ser oriunda de uma instituição governamental de pesquisa responsável pela coleta dos dados censitários no Brasil, muitas vezes, é tomada como definição "oficial", sendo amplamente utilizada em pesquisas e em planejamento urbano e regional, todavia, nem sempre sendo explorados, pelos usuários das informações censitárias, os critérios e os métodos utilizados pelo Instituto na elaboração das bases cartográficas utilizadas para fins censitários e coleta de dados, mesmo sendo tais informações fundamentais para avaliação dos limites e potencialidades dos dados, ponderando-se sua eficácia para as finalidades propostas em cada pesquisa.

Tem-se no IBGE, criado em 1936, uma referência internacional quanto ao sistema de informações estatísticas e demográficas nacionais, especialmente no contexto dos países latino-americanos. 0 Brasil - país continental, de economia periférica e com múltiplos contextos socioambientais e generalizada desigualdade - realiza censos demográficos decenais desde 1940, mapeando informações geográficas e administrativas, além de outras importantes pesquisas e serviços que possibilitaram a identificação e o auxilio na construção de políticas públicas voltadas ao enfrentamento das equidades regionais em nosso território.

Neste artigo se discutem as contribuições que a classificação da situação, urbana ou rural, dos setores censitários definidos pelo IBGE pode trazer para o estudo da expansão urbana contemporânea, em especial quanto a limites e possibilidades desses dados para a compreensão da estruturação do território além da dicotomia urbano-rural. Ressalta-se que este artigo não tem como enfoque a elaboração de uma categorização a respeito do que se entende por rural ou urbano nem visa a questionar se o Brasil é mais ou menos urbano do que se imagina, como propõe Veiga (2003); mas, sim, a debater como a variável pode, ou não, ser utilizada para análise da expansão urbana e para a identificação de espaços além da dicotomia urbano-rural.

A pesquisa explorou o reagrupamento das tipologias de setores propostas pelo IBGE, cruzando-as também com variáveis do IBGE relacionadas às características do entorno urbanístico dos domicílios, caracterizando desigualdades do espaço urbano por meio da espacialização do acesso a serviços públicos de infraestrutura urbana.

Buscou-se, com este estudo, verificar como dados do IBGE podem ser utilizados para auxílio na construção e gestão de políticas públicas, pontuando também os esforços e a relevância das informações coletadas pelo Instituto, pois muito se menciona a respeito da impossibilidade de utilização desses dados para estudo da expansão urbana contemporânea, porém poucas são as informações sistematizadas a respeito dos pros e contras de sua utilização. Este artigo, fruto de uma pesquisa 
que estudou o processo contemporâneo de expansão urbana da Região Metropolitana de Campinas, por meio da análise da legislação urbanística e das lógicas de produção atuantes no espaço urbano (Pera, 2016), traz uma análise crítica sistematizada acerca de um tema controverso que, apesar de já ter sido muitas vezes debatido, desta vez detalha elementos importantes para novas leituras sobre o uso de dados censitários.

\section{A definição do IBGE a respeito da situação urbana ou rural dos setores censitários}

Segundo o IBGE, o que define um setor censitário como urbano ou rural é sua posição em relação ao perímetro urbano contido na legislação urbanística municipal. Porém, caso o município não possua legislação que regulamente essas áreas, cabe ao próprio IBGE, com a devida aprovação municipal, estabelecer um "perímetro urbano para fins de coleta censitária". Por serem, os setores censitários, a unidade territorial de coleta para fins censitários no Brasil, a quantificação dos domicílios e da população urbana segue esses mesmos parâmetros em nosso País.

0 IBGE se pauta, portanto, principalmente em definições legais para caracterizar a área urbana e a rural dos municípios. Contudo, não foram encontradas informações na bibliografia do Instituto que explicitem quais os critérios utilizados para delimitação do que denominam "perímetro para fins de coleta censitária", necessário nos casos de ausência de lei municipal que regulamente o perímetro urbano.
Na publicação Metodologia do Censo 2010 (IBGE, 2013), apenas se menciona que, para a elaboração das bases cartográficas que orientaram a delimitação dos setores do Censo 2010, houve reuniões periódicas das chamadas "Comissões Municipais de Geografia e Estatística". Criadas por iniciativa do IBGE, essas comissões são constituídas por representantes municipais, que têm a função de acompanhar o preparo da base territorial municipal para o censo e de minimizar questões polêmicas sobre limites territoriais surgidas durante o processo, tais como: a administração local considera que a lei não reflete a realidade; o perímetro urbano ultrapassa o limite municipal; e na ausência de lei definidora de perímetro urbano. ${ }^{2}$

Como as informações contidas nos cadernos metodológicos do IBGE não são suficientes para a compreensão do método para traçar os perímetros utilizados para fins de coleta censitária, fez-se contato, por e-mail, com o setor técnico do IBGE, na tentativa de obter mais informações a respeito do método utilizado para classificação da situação urbana e rural dos setores censitários. Segundo o setor técnico de atendimento do IBGE (2015):

Ao classificar seus setores censitários conforme a condição urbana/rural, o IBGE leva em consideração alguns critérios:

1) 0 estado de direito, estabelecido através de legislação municipal (de perímetro urbano, zoneamento ou macrozoneamento, tributos, etc.) quando for possível sua efetiva representação cartográfica;

2) 0 estado de fato, quando não existe legislação ou quando a mesma se apresenta desatualizada em relação à expansão da cidade ou da vila, tomando por base imagens, cartografia e observações de campo (realizadas não pelo agente 
de coleta, mas pelos servidores do IBGE sob orientação das Supervisões de Base Territorial nos estados), levando em consideração o parcelamento, uso efetivo do solo e a densidade construtiva. Trata-se de uma classificação para fins censitários que também pode ocorrer em áreas urbanizadas que "extrapolam" o limite da zona urbana fixada em lei.

3) Elementos do meio físico de fácil percepção em campo que facilitem a identificação dos respectivos limites setoriais a partir do percurso da coleta - esse critério pode justificar algumas diferenças entre legislação municipal e limites de setores, especialmente quando aquela se vale de linhas secas de difícil identificação em campo. (E-mail da equipe técnica de atendimento do IBGE, 2015; grifos da autora)

Diante do exposto, pode-se afirmar que - IBGE também utiliza informações sobre a realidade instaurada para delimitação da situação urbana e rural, principalmente em municípios que não possuem legislação municipal que regulamente o perímetro urbano. Logo, a definição da situação rural ou urbana, segundo o IBGE, é uma informação híbrida, heterogênea, pois parte tanto de fontes legais, quanto analíticas. É preciso ainda destacar que não fica claro, no banco de dados acessível aos usuários da informação, para quais municípios o IBGE utiliza a lei de perímetro urbano e para quais utiliza o perímetro traçado pelo próprio órgão. Seria essencial que o IBGE passasse a incorporar esse conhecimento ao banco de dados, possibilitando acesso pleno à fonte da informação.

\section{A utilização da variável \\ "situação do setor censitário": limites para caracterização da expansão urbana contemporânea}

Conforme verificado por esta pesquisa, pode-se utilizar a variável "situação do setor censitário" de duas formas diferentes. A primeira forma de utilização estrutura o território em duas situações: a urbana e a rural, conforme se observa no Mapa 1. A leitura desse primeiro mapa, desconhecendo-se as características das duas categorias de setores censitários utilizadas, pode causar a impressão de que a região estudada ${ }^{3}$ se apresenta muito mais urbana do que de fato é, além de indicar territorialmente a ocorrência de um processo de expansão urbana, entre os anos 2000 e 2010, superior ao ocorrido na realidade.

A segunda possibilidade de utilização da variável mapeia os setores a partir de oito tipologias quanto à situação urbana ou rural. A sistematização da definição das oito categorias - segundo o Censo 2010, Banco Multidimensional de Estatísticas-Relatório - e do método utilizado pelo IBGE para delimitação de cada tipo de situação de setor censitário encontram-se no Quadro 1. Devido à ausência de informações na bibliografia do IBGE (2010), a respeito do método utilizado para classificar os setores nas oito categorias, foram utilizadas, novamente, as informações obtidas a partir de contato direto com o IBGE por e-mail. Outra fonte utilizada foi o Manual de Delimitação 
dos Setores do Censo 2000 (IBGE, s/d.) no qual constam informações a respeito da delimitação das chamadas "áreas de apuração". 4

Atualmente $^{5}$ há, na categorização do Instituto, três tipologias de situação urbana: 1) área urbanizada de cidade ou vila; 2) área não urbanizada de cidade ou vila; e 3) área urbana isolada. As cinco categorias de situação rural atuais são: 1) aglomerado rural de extensão urbana; 2) aglomerado rural isolado - povoado; 3) aglomerado rural isolado -núcleo; 4) aglomerado rural isolado - outros aglomerados; e 5) zona rural, exclusive aglomerados rurais.

Assim como a distinção em duas situações, urbana ou rural, a classificação a partir de oito categorias também possui caráter híbrido quanto à origem das informações - conforme pode ser analisado por meio das informações contidas no Quadro 1 -, pois pauta-se tanto na legislação urbanística, quanto na realidade instaurada -, uma vez que se baseia no número de domicílios e na contiguidade territorial para mapear os aglomerados rurais. Utiliza também dados referentes ao tipo de uso do solo para definição das áreas de apuração dos tipos: áreas urbanas, urbanas não urbanizadas e aglomerados rurais.

A espacialização das oito categorias para a região estudada pode ser observada por meio do Mapa 2, que revela um quadro bastante diferente do encontrado no Mapa 1. Além da comparação dos mapas entre si, ao se comparar esses mapas com outras fontes de informação, como imagens de satélite da região estudada, percebeu-se que o entendimento dos processos fica comprometido sem o conhecimento da definição de cada uma das oito categorias e dos critérios utilizados pelo
IBGE para delimitação das situações urbanas e rurais, durante o processo de elaboração da base cartográfica, para fins de coleta censitária, induzindo o leitor - gestor, pesquisador, estudante - à falsa leitura sobre a realidade instaurada no território.

A leitura do Mapa 1, quando não associada ao Quadro 1 - ou seja, se ambos forem analisados de forma isolada, sem o conhecimento a respeito das definições e dos métodos utilizados para coleta e sistematização dos dados pelo IBGE -, pode causar a impressão de que a região analisada se apresenta muito mais urbana do que de fato é, além de indicar a ocorrência de uma expansão da área urbana, entre os anos 2000 e 2010, superior à ocorrida na realidade. Por meio da comparação entre o Mapa 1 e o Mapa 2, nota-se que o primeiro mascara muitas informações relativas ao território, que se tornam visíveis somente a partir do desmembramento da região em mais categorias de análise, como no Mapa 2.

Diante do exposto, apesar de ser muito comum a utilização dos setores censitários para mapeamento das áreas urbanas e rurais, este não é o método mais apropriado para caracterização da expansão das áreas urbanizadas. Conforme vimos até aqui, os setores censitários, divididos de acordo com sua situação: urbana ou rural, ilustram uma informação híbrida, que tanto pode pautar-se no perímetro urbano municipal, representando a área legalmente urbana, quanto em situações da realidade instaurada, caracterizando um território de fato urbanizado. Entretanto, como o IBGE não disponibiliza informações a respeito da fonte utilizada para traçar esse perímetro urbano para fins de coleta censitária em cada um dos 
municípios brasileiros, torna-se difícil utilizar tais dados para analisar a expansão urbana contemporânea, legal ou real.

Além disso, o método utilizado no Mapa 2, apesar de possibilitar uma leitura mais complexa a respeito do território, também mascara dados a respeito da realidade legal e de fato instaurada. Isso ocorre, além das limitações acima apontadas, devido a limitações oriundas da chave de classificação proposta pelo IBGE e do método utilizado para coleta de cada uma das categorias.

Por exemplo, a categoria 1 (área urbana de cidade ou vila) mascara informações quanto à presença de vazios urbanos, pois, apesar de a categoria 2 (área urbana não urbanizada) ter como objetivo mapear as áreas vazias inseridas em área urbana legal, essa categoria só leva em consideração as áreas ocupadas com atividades agropastoris (lavoura, pecuária e atividades extrativas) e terras ociosas (sem qualquer uso) quando não contíguas às áreas urbanas de cidade ou vila intensamente ocupadas com edificações, ruas, praças, etc. (IBGE, s/d). Sendo assim, nota-se que a categoria 2 não dá conta do mapeamento de todas as áreas urbanas não urbanizadas, o que dificulta a utilização desses dados pelo planejamento municipal para quantificação de vazios urbanos.

\section{Quadro 1 - Definição das oito categorias de setor urbano e rural e critérios utilizados pelo IBGE para sua para delimitação}

\begin{tabular}{|c|c|c|}
\hline $\begin{array}{l}\text { Situação } \\
\text { do Setor }\end{array}$ & $\begin{array}{l}\text { Definição da Situação do Setor } \\
\text { Censitário (Censo 2010) }\end{array}$ & $\begin{array}{l}\text { Método para Classificar a Área de Apuração e/ou os Setores Censitários: } \\
\text { (IBGE, s/d-a) e e-mail do setor técnico de atendimento do IBGE (2015) }\end{array}$ \\
\hline $\begin{array}{l}\text { 1. Área urbanizada } \\
\text { de cidade ou vila } \\
\text { (Urbana) }\end{array}$ & $\begin{array}{l}\text { "Setor urbano situado em áreas legalmente } \\
\text { definidas como urbanas, caracterizadas } \\
\text { por construções, arruamentos e intensa } \\
\text { ocupação humana; áreas afetadas } \\
\text { por transformações decorrentes do } \\
\text { desenvolvimento urbano e aquelas } \\
\text { reservadas à expansão urbana." }\end{array}$ & $\begin{array}{l}\text { "Constituem áreas urbanizadas: } \\
\text { I) Áreas intensamente ocupadas com edificações, ruas e praças, etc.; } \\
\text { II) Áreas com uso do solo menos intenso que os da categoria I, onde se identifica } \\
\text { a presença de reservatórios d'água, áreas de lazer, cemitérios, estações } \\
\text { agrícolas experimentais, depósitos ligados à atividade industrial ou comercial, } \\
\text { aterros sanitários, etc., formando um espaço contínuo com o da I. } \\
\text { III) Áreas reservadas à expansão urbana, isto é, terras ociosas, sem qualquer uso } \\
\text { rural, ainda não ocupadas por construções ou equipamentos urbanos, contíguas } \\
\text { às áreas incluídas na categoria I e ou II." (IBGE, s/d) }\end{array}$ \\
\hline $\begin{array}{l}\text { 2. Área não } \\
\text { urbanizada de } \\
\text { cidade ou vila } \\
\text { (Urbana) }\end{array}$ & $\begin{array}{l}\text { "Área não urbanizada de vila ou cidade, } \\
\text { setor urbano situado em áreas localizadas } \\
\text { dentro do perímetro urbano de cidades } \\
\text { e vilas reservadas à expansão urbana } \\
\text { ou em processo de urbanização; áreas } \\
\text { legalmente definidas como urbanas, } \\
\text { mas caracterizadas por ocupação } \\
\text { predominantemente de caráter rural" }\end{array}$ & $\begin{array}{l}\text { "Constituem áreas não urbanizadas: } \\
\text { I) Áreas ocupadas com atividades agropastoris (lavouras em geral, pecuária) e } \\
\text { atividades extrativas. } \\
\text { II) Terras ociosas, sem qualquer uso, não contíguas às áreas urbanizadas dos } \\
\text { tipos I e II (IBGE, s/d-a). } \\
\text { Nota: A situação } 2 \text { (área urbana não urbanizada) só é cadastrada na Base } \\
\text { Territorial mediante existência de Lei Municipal. Quando esta não existe (fato } \\
\text { que se dá para aproximadamente } 1 / 5 \text { dos municípios, segundo a pesquisa } \\
\text { Munic), o IBGE não classificará setores segundo tal situação." (E-mail da equipe } \\
\text { técnica de atendimento do IBGE, 2015) }\end{array}$ \\
\hline $\begin{array}{l}\text { 3. Área urbana } \\
\text { isolada (Urbana) }\end{array}$ & $\begin{array}{l}\text { "Setor urbano situado em áreas definidas } \\
\text { por lei municipal e separadas da sede } \\
\text { municipal ou distrital por área rural ou por } \\
\text { um outro limite legal." }\end{array}$ & $\begin{array}{l}\text { "A situação } 3 \text { (área urbana isolada) só é cadastrada na Base Territorial mediante } \\
\text { existência de lei municipal. Quando esta não existe (fato que se dá para } \\
\text { aproximadamente } 1 / 5 \text { dos municípios, segundo a pesquisa Munic), o IBGE não } \\
\text { classificará setores segundo tais situações. O IBGE toma o cuidado de cadastrar } \\
\text { a área urbana isolada apenas quando efetivamente ocupada, pois não são raros } \\
\text { os casos em que uma determinada área é reservada, através de lei, para um } \\
\text { determinado empreendimento que acaba não se efetivando." (E-mail da Equipe } \\
\text { técnica de atendimento do IBGE, 2015) }\end{array}$ \\
\hline
\end{tabular}




\begin{tabular}{|c|c|c|}
\hline $\begin{array}{l}\text { 4. Aglomerado rural } \\
\text { de extensão urbana } \\
\text { (Rural) }\end{array}$ & $\begin{array}{l}\text { "Setor rural situado em assentamentos em } \\
\text { área externa ao perímetro urbano legal, } \\
\text { mas desenvolvidos a partir de uma cidade } \\
\text { ou vila, ou por elas englobados em sua } \\
\text { extensão". }\end{array}$ & $\begin{array}{l}\text { "[...] Por constituírem uma simples extensão da área efetivamente urbanizada, } \\
\text { atribui-se, por definição, caráter urbano aos aglomerados rurais desse tipo. } \\
\text { Tais assentamentos podem ser constituídos por loteamentos já habitados, } \\
\text { conjuntos habitacionais, aglomerados de moradias ditas subnormais ou núcleos } \\
\text { desenvolvidos em torno de estabelecimentos industriais, comerciais ou de } \\
\text { serviços. } \\
\text { Na sua identificação, deve-se obedecer, além dos critérios de tamanho e } \\
\text { densidade, a a um critério a eles específico: o de contiguidade, que estabelece } \\
\text { que a distância entre este e o núcleo principal da cidade ou vila deve ser inferior } \\
\text { a } 1 \text { km. Serão considerados, também, os aglomerados rurais cuja contiguidade } \\
\text { se estabeleça em relação a outros aglomerados rurais do tipo extensão urbana, } \\
\text { desde que pelo menos um desses aglomerados tenha sido definido como } \\
\text { contíguo a uma cidade ou vila, não sendo necessário que a cidade ou vila e } \\
\text { os aglomerados rurais a elas contíguos estejam situados na mesma unidade } \\
\text { administrativa." (IBGE, s/d-a) }\end{array}$ \\
\hline $\begin{array}{l}\text { 5. Aglomerado rural } \\
\text { isolado } \text { povoado }^{\text {(Rural) }}\end{array}$ & $\begin{array}{l}\text { "Setor situado em aglomerado rural isolado } \\
\text { sem caráter privado ou empresarial, ou } \\
\text { seja, não vinculado a um único proprietário } \\
\text { do solo (empresa agrícola, indústria, usina, } \\
\text { etc.), cujos moradores exercem atividades } \\
\text { econômicas no próprio aglomerado ou } \\
\text { fora dele. Caracteriza-se pela existência } \\
\text { de um número mínimo de serviços ou } \\
\text { equipamentos para atendimento aos } \\
\text { moradores do próprio aglomerado ou de } \\
\text { áreas rurais próximas". }\end{array}$ & $\begin{array}{l}\text { "Povoado é o aglomerado cujos moradores exercem atividades econômicas, } \\
\text { quer primárias (extrativismo vegetal, animal e mineral, e atividades } \\
\text { agropecuárias), terciárias (equipamentos e serviços) ou, mesmo, secundárias } \\
\text { (indústrias em geral) no aglomerado ou fora dele. É caracterizado pela existência } \\
\text { de serviços para atender aos moradores do próprio aglomerado ou de áreas } \\
\text { rurais próximas. Devendo possuir: } \\
\text { - Pelo menos } 1 \text { estabelecimento comercial de venda de bens de consumo } \\
\text { frequente e pelo menos } 2 \text { dos } 3 \text { serviços ou equipamentos abaixo: } \\
\text { - um estabelecimento de ensino de } 1^{\circ} \text { grau com turmas de } 1^{\circ} \text { segmento com } \\
\text { funcionamento regular. } \\
\text { - um posto de saúde, com atendimento regular e em funcionamento e/ou, } \\
\text { - um templo religioso de qualquer credo. Além dos critérios de tamanho e } \\
\text { densidade comuns a todos os aglomerados rurais". }{ }^{10} \text { (IBGE, s/d-a) }\end{array}$ \\
\hline $\begin{array}{l}\text { 6. Aglomerado rural } \\
\text { isolado"11 núcleo } \\
\text { (Rural) }\end{array}$ & $\begin{array}{l}\text { "Setor rural situado em aglomerado rural } \\
\text { isolado, vinculado a um único proprietário } \\
\text { do solo (empresa agrícola, indústria, usina, } \\
\text { etc.), privado ou empresarial, dispondo } \\
\text { ou não dos serviços ou equipamentos } \\
\text { definidores dos povoados". }\end{array}$ & $\begin{array}{l}\text { "É considerado, como característica definidora desse tipo de aglomerado rural } \\
\text { isolado, seu caráter privado ou empresarial. Além dos critérios de tamanho e } \\
\text { densidade comuns a todos os aglomerados rurais". }{ }^{2} \text { (IBGE, s/d-a) }\end{array}$ \\
\hline $\begin{array}{l}\text { 7. Aglomerado rural } \\
\text { isolado } \\
\text { Outros aglomerados } \\
\text { (Rural) }\end{array}$ & $\begin{array}{l}\text { "Setor rural situado em outros tipos de } \\
\text { aglomerados rurais, que não dispõem, } \\
\text { no todo ou em parte, dos serviços ou } \\
\text { equipamentos definidores dos povoados } \\
\text { e que não estão vinculados a um único } \\
\text { proprietário (empresa agrícola, indústria, } \\
\text { usina, etc.)." }\end{array}$ & $\begin{array}{l}\text { "São aqueles que não dispõem, no todo ou em parte, dos serviços ou } \\
\text { equipamentos definidores dos povoados e que não então vinculados a um único } \\
\text { proprietário. Serão classificados como aglomerados rurais somente aqueles que } \\
\text { apresentarem mais de } 10 \text { e menos de } 51 \text { domicílios, não constituindo, portanto, } \\
\text { área de apuração. Além dos critérios de tamanho e densidade comuns a todos } \\
\text { os aglomerados rurais". }{ }^{14} \text { (IBGE, s/d) }\end{array}$ \\
\hline $\begin{array}{l}\text { 8. Zona rural } \\
\text { exclusive aglomera- } \\
\text { dos rurais (Rural) }\end{array}$ & \multicolumn{2}{|c|}{ "Área externa ao perímetro urbano, exclusive as áreas de aglomerado rural." (IBGE, s/d) } \\
\hline
\end{tabular}

Elaboração: Pelas autoras, 2016. A fonte das informações de cada coluna encontra-se em nota de rodapé. 
Mapa 1 - Sobreposição dos setores urbanos e rurais da RMC

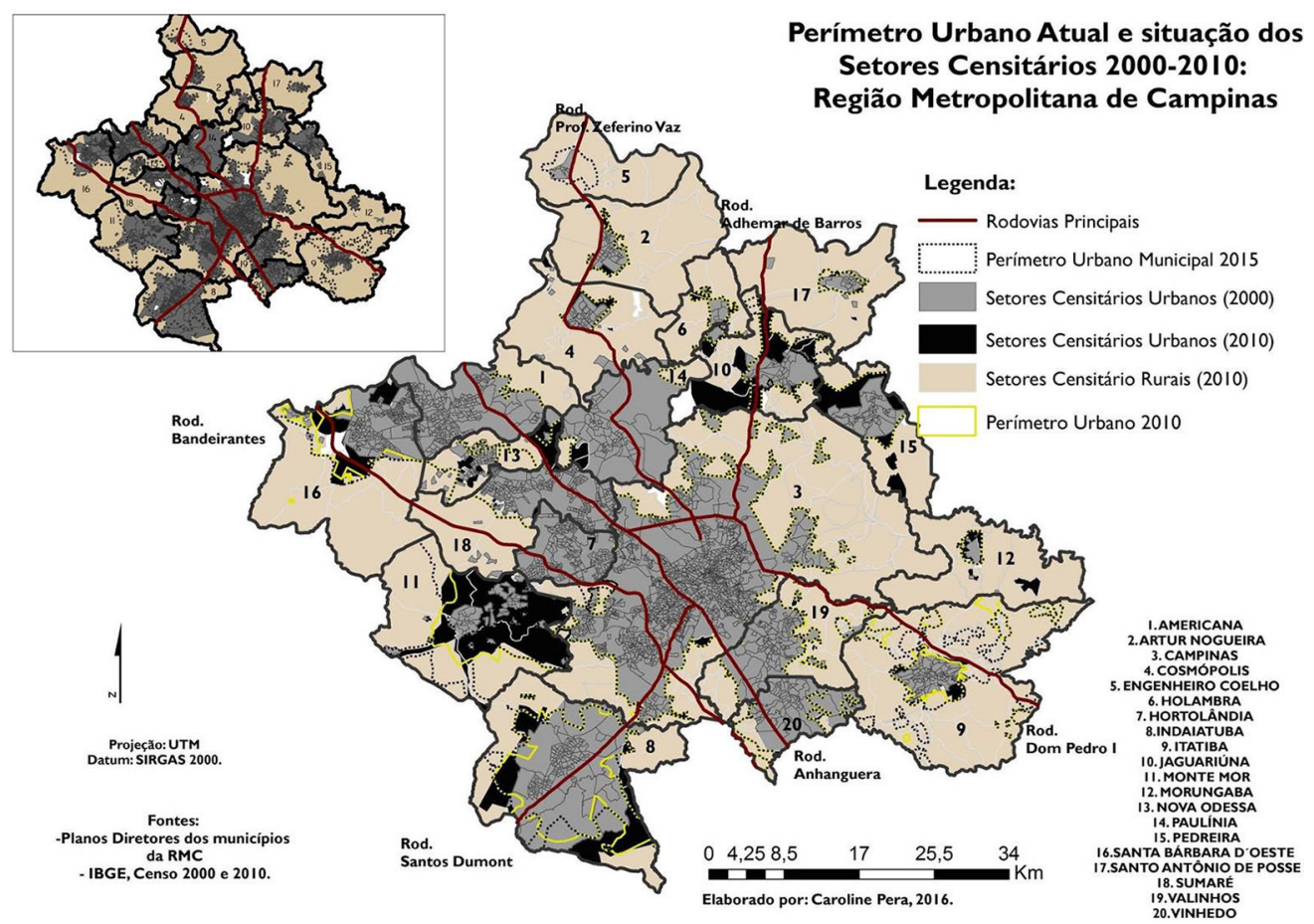

Fonte: IBGE (2000 e 2010). Elaboração: Caroline Pera (2016). 
Mapa 2 - RMC- Setores urbanos e rurais subdivididos em oito categorias

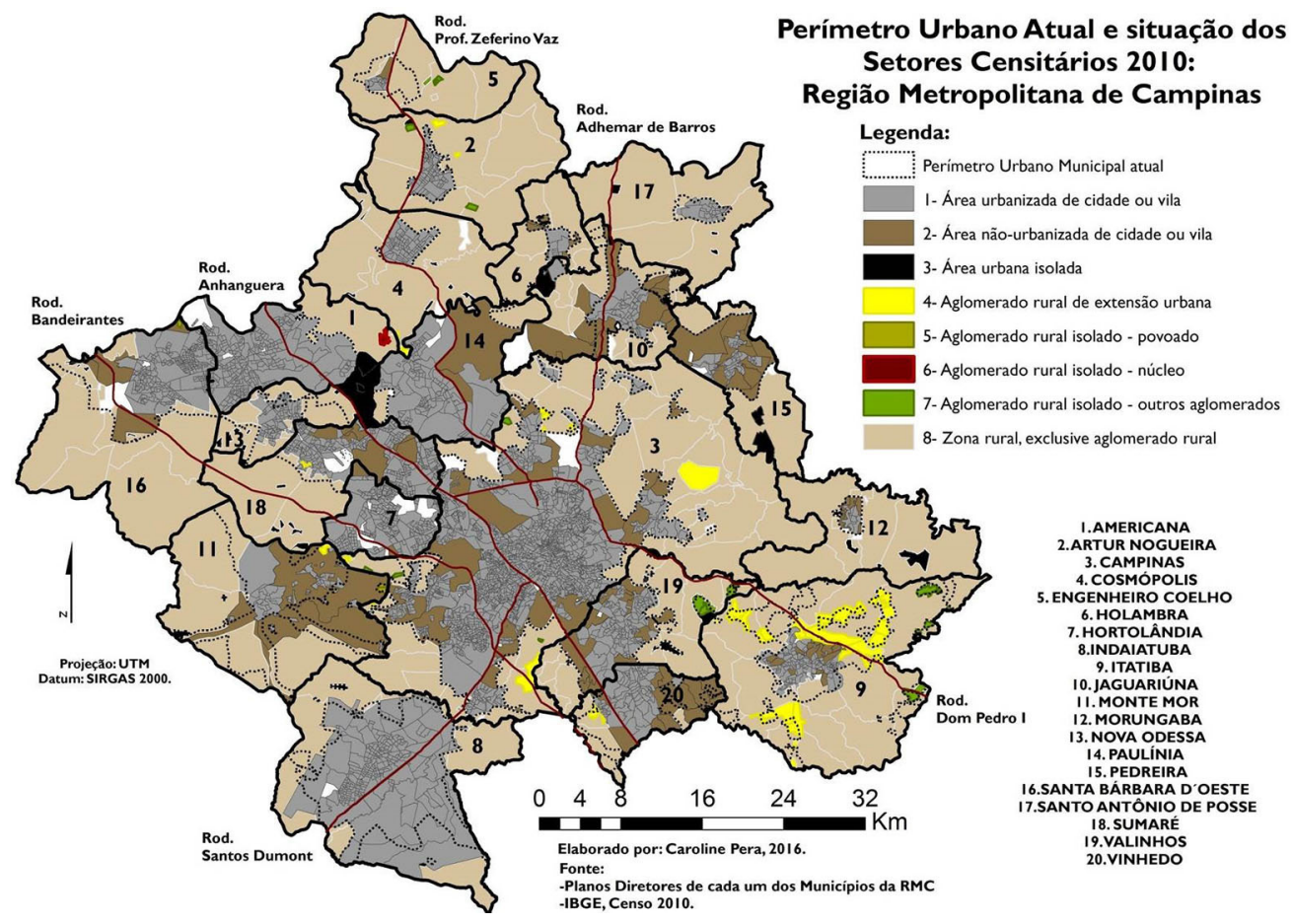

Fonte: Vide mapa. Elaboração: Caroline Pera (2016). 
A utilização da variável "situação do setor censitário": potencialidades para caracterização da expansão urbana contemporânea

Apesar das fragilidades apontadas no item anterior, buscou-se nesta pesquisa verificar a possibilidade de utilização dos dados da situação dos setores censitários por meio do cruzamento de informações. Desenvolveu-se, então, um método para caracterizar o processo de expansão urbana no contexto metropolitano, encontrando "padrões espaciais de análise da expansão urbana contemporânea", por meio da sobreposição de dados de dois diferentes censos demográficos, conforme o Mapa 3.
Quanto ao método utilizado para identificar esses "padrões espaciais de análise da expansão urbana contemporânea", parte-se da análise conjunta do Mapa 3 e do Quadro 2. Os dados das colunas 1 e 2 do Quadro 2 foram cruzados a partir da compreensão das definições teóricas sobre cada um dos oito tipos de situação urbana ou rural sistematizadas no Quadro 1. Identificaram-se, com esse cruzamento das colunas 1 e 2, possíveis características a respeito de transformações espaciais ocorridas entre os Censos 2000 e 2010. Essas características foram sistematizadas na coluna 3 do Quadro $2 .{ }^{15}$ Na coluna 4 estão elencados os municípios nos quais se verifica a ocorrência dos padrões espaciais identificados. Por último,

Mapa 3 - RMC - Sobreposição dos setores urbanos e rurais em oito categorias em 2000 e 2010

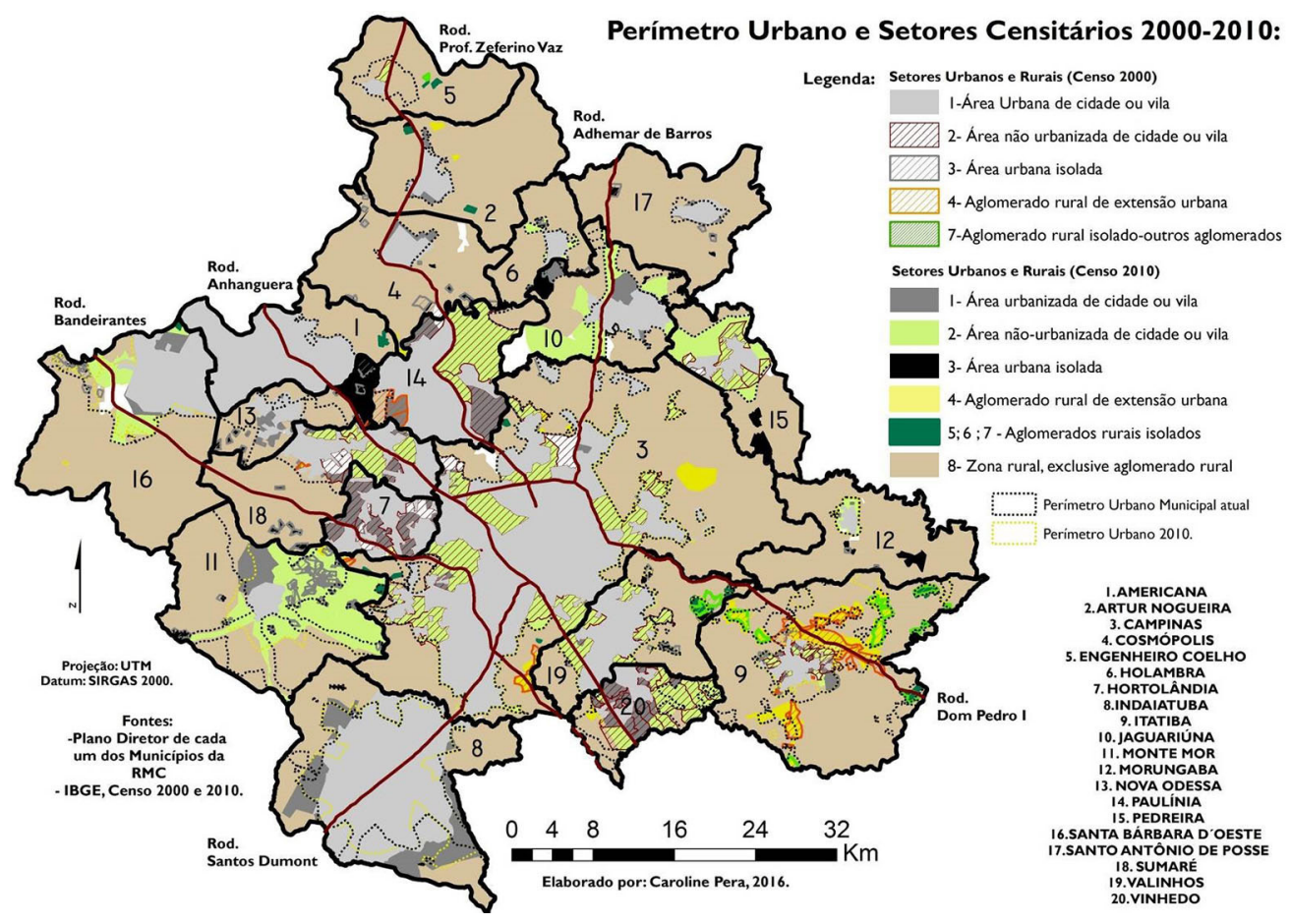

Fonte e elaboração: Vide mapa. 
Revendo o uso de dados do IBGE...

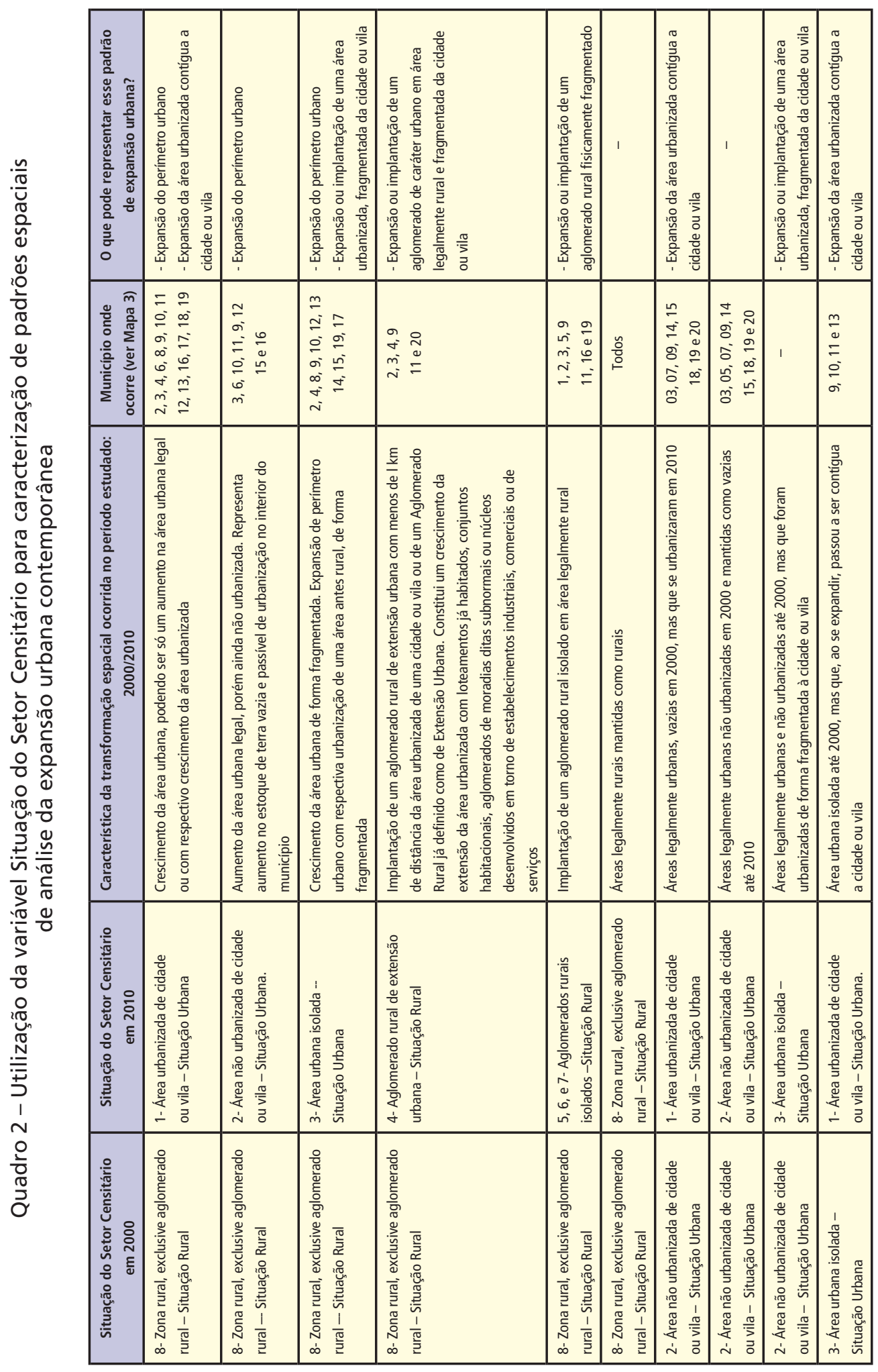




\begin{tabular}{|c|c|c|c|c|c|c|c|c|c|}
\hline 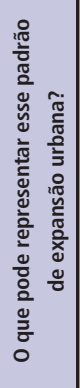 & 1 & 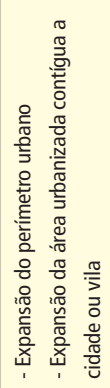 & 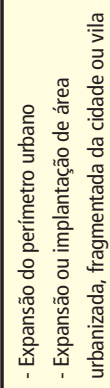 & 1 & 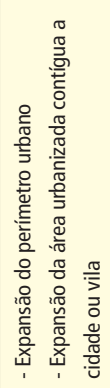 & 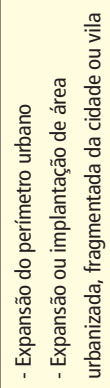 & 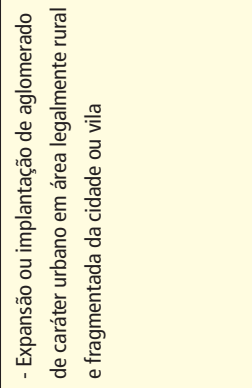 & 1 & 1 \\
\hline 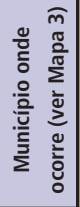 & 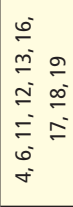 & 1 & \pm & $\begin{array}{l}\infty \\
\stackrel{\infty}{\sigma} \\
\dot{m}^{\prime}\end{array}$ & 1 & 1 & $\sigma$ & $\begin{array}{l}\frac{\sigma}{\sigma} \\
\sigma \\
\text { in }\end{array}$ & $\begin{array}{l}\text { : } \\
\text { 응 }\end{array}$ \\
\hline 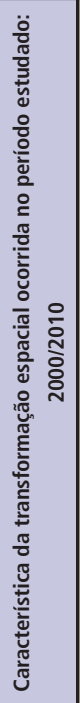 & 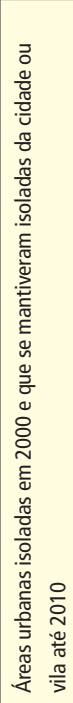 & 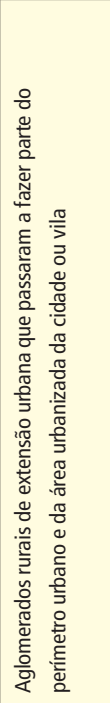 & 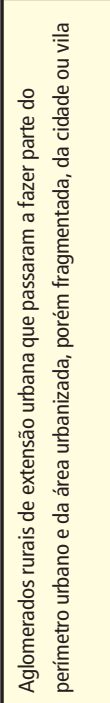 & 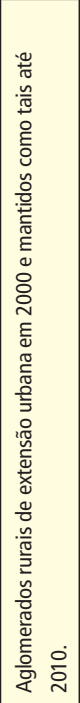 & 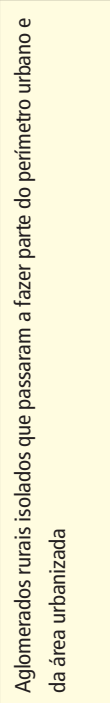 & 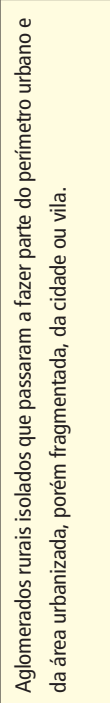 & 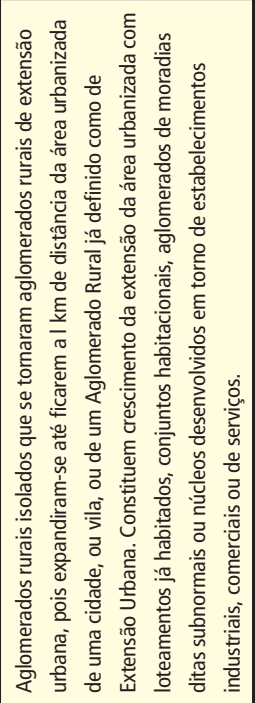 & 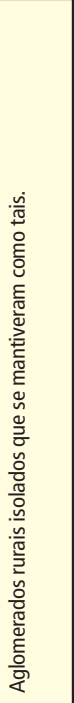 & 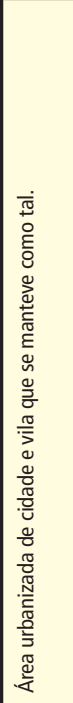 \\
\hline 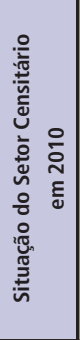 & 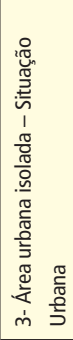 & 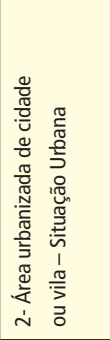 & 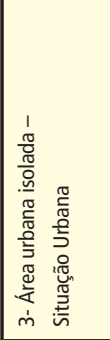 & 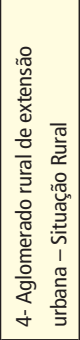 & 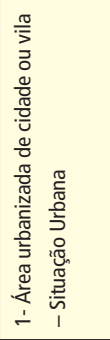 & 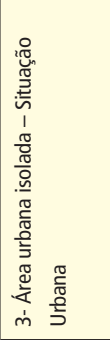 & 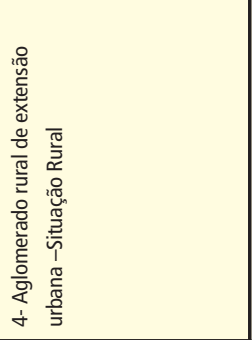 & 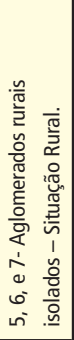 & 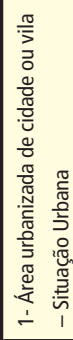 \\
\hline 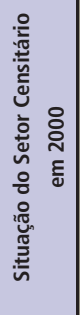 & 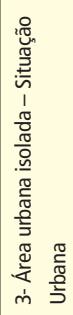 & 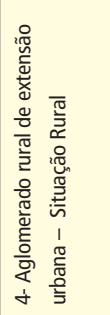 & 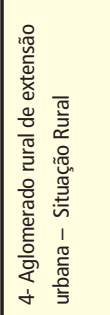 & 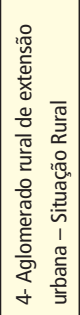 & 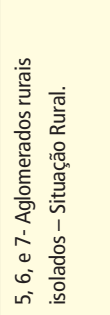 & 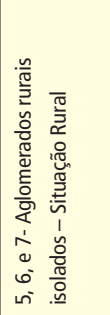 & 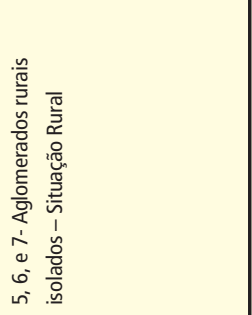 & 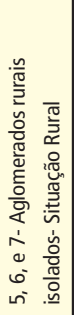 & 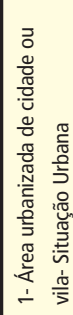 \\
\hline
\end{tabular}


da coluna 5, constam os "padrões espaciais de análise da expansão urbana contemporânea" identificados. Por meio desse método, foi possível mapear se houve:

- aumento da área urbanizada contígua à cidade ou vila;

- expansão da área urbanizada de forma fragmentada em relação à cidade ou vila;

- aumento da área urbana legal através do aumento do perímetro urbano;

- expansão de aglomerados rurais;

- expansão de aglomerados rurais de caráter urbano em área rural.

É importante mencionar que as informações contidas na coluna 5 podem ilustrar uma hipótese acerca do real ou uma informação espacial concreta. As células com coloração branca na tabela representam situações que de fato se consolidaram no território, enquanto as células em cinza representam uma situação hipotética, ou seja, que precisa ser comprovada através de outras fontes de informações, como, por exemplo, imagens de satélite ou legislação urbanística.

Através do Quadro 2 e do Mapa 3, constata-se que é possível traçar padrões espaciais de análise da expansão urbana utilizando a variável "situação do setor" e dados de diferentes censos demográficos. A partir desse estudo, pode-se mapear tanto expansões da área urbanizada, quanto o crescimento das áreas legalmente urbanas.

Há cinco tipos de definições espaciais de expansão urbana possíveis de serem mapeados: 1) aumento da área urbanizada contígua a cidade ou vila; 2) expansão da área urbanizada de forma fragmentada em relação a cidade ou vila; 3) aumento da área urbana legal através do aumento do perímetro urbano; 4) expansão de aglomerados rurais; e 5) expansão de aglomerados rurais de caráter urbano em área rural.

Como pode ser observado no Quadro 2, por meio de sete tipos de cruzamento, pode-se mapear a expansão de perímetro urbano; por quatro tipos de cruzamento, a expansão das áreas urbanizadas contíguas a cidade ou vila. Outros quatro tipos mapeiam tendências de urbanização fragmentada - um tipo mapeia a expansão de aglomerados rurais, e, por meio de dois tipos de cruzamento, é possível mapear a expansão de aglomerados de caráter urbano em área rural. Os dois últimos padrões citados também podem ser utilizados para caracterizar expansão da urbanização fragmentada.

Frisa-se que este é um estudo complementar, realizado com o intuito de caracterizar, demograficamente ou a partir de aspectos socioeconômicos, as áreas de expansão urbana e/ou recentemente urbanizadas, contribuindo para o mapeamento de situações, tais como: identificação do crescimento das áreas urbanizadas contíguas a cidade ou vila; identificação do crescimento de áreas urbanizadas fragmentadas do tecido urbano consolidado; identificação da expansão de aglomerados rurais e de aglomerados de caráter urbano em área rural. Caso o intuito da pesquisa fosse caracterizar 0 processo de expansão urbana contemporâneo, o mais indicado seria pautar-se por imagens de satélite - para o estudo do crescimento das áreas urbanizadas - e por legislação urbanística municipal se o objetivo fosse mapear a expansão das áreas legalmente urbanas. 


\section{A utilização da variável "situação do setor censitário": estruturação do espaço além da dicotomia urbano-rural}

Segundo Souza (2005), espaços além da dicotomia urbano-rural podem ser chamados de "faixa de transição" entre o uso da terra tipicamente rural e urbano ou ainda de espaço periurbano e franjas da cidade.

Essa faixa de transição é chamada, entre os geógrafos anglo-saxões, de franja rural-urbana, e, entre os franceses, comumente, de espaço periurbano. No Brasil ambas as expressões são empregadas pelos estudiosos. Quanto maior a cidade, em geral, mais complexo tende a ser o espaço periurbano. Nele se encontram misturadas duas "lógicas", por assim dizer, de uso da terra: a rural e a urbana. (Ibid., p. 27)

Spósito (2013), tomando como referência os estudos urbanos, menciona a existência de quatro tipos de vertentes que estudam o espaço urbano e rural. A primeira vertente relaciona a questão cidade-campo a partir da concentração demográfica, por uma análise que caracteriza o que é campo e o que é cidade pela diferenciação entre esses espaços, sendo o campo o local onde a concentração demográfica é inferior à encontrada na área urbana. A segunda vertente articula a relação campo-cidade a partir da diferenciação social, ou seja, identifica que a divisão social do trabalho existe nos dois espaços, compreendendo o campo e a cidade como par dialético, mesmo sendo maiores os conflitos da divisão social do trabalho na cidade do que no campo. A terceira vertente relaciona campo e cidade a partir da diferenciação entre unidade espacial. A última vertente caracteriza campo-cidade a partir das descontinuidades territoriais, como dispersão e fragmentação urbana, configuradoras de espaços mais extensos e com alterações consideráveis na morfologia, tornando ainda mais difícil distinguir, no plano das formas espaciais, a cidade e o campo.

A atual categorização dos setores para fins censitários no Brasil, apesar de dividida em oito categorias, orienta uma leitura do espaço em apenas duas realidades, a urbana e a rural. Não sendo mencionada a existência de espaços além dessa dicotomia. Entretanto, quando se analisam as definições (Quadro 1) e se realiza a análise espacial (Mapa 3), é possível encontrar situações que rompem essa dicotomia nas categorias 2, 3 e 4, (conforme os setores hachurados no Mapa 3).

Na categoria 2 são mapeadas as áreas legalmente urbanas ainda com uso do solo rural. Na categoria 3 são mapeadas as áreas urbanas isoladas, portanto, áreas urbanas inseridas em contexto de entorno rural. Na categoria 4, há as áreas que, mesmo caracterizadas como aglomerados de extensão urbana, por estarem fora do perímetro urbano, são entendidas pelo IBGE como rurais, sendo áreas que constituem loteamentos habitados em áreas rurais, conjuntos habitacionais, aglomerados subnormais ou núcleos desenvolvidos em torno de estabelecimentos industriais, comerciais ou de serviços. 
Espacialização de dados do Censo 2010

para compreensão de desigualdades

no espaço intraurbano

A cidade brasileira apresenta fortes diferenças no padrão de urbanização, refletindo o histórico dos investimentos públicos, dos processos informais de urbanização e do perfil socioeconômico da população. 0 Mapa 4 representa uma leitura da região estudada a partir do reagrupamento das oito categorias de setores censitários, como discutido nos itens anteriores, em três grupos: urbano, rural e além da dicotomia urbano-rural.

0 espaço urbano é representado apenas pela classificação 1 - setores urbanos de cidade e vila; o espaço rural é representado pelo agrupamento das categorias 5, 6, 7, 8; o espaço com dinâmicas híbridas, relacionadas a novas espacialidades além do urbano ou rural, é composto pelas categorias $2,3,4$, respectivamente: área não urbanizada de vila ou cidade, área urbana isolada e área rural de extensão urbana.

Para incorporar a problemática da desigualdade ao acesso às redes de infraestrutura urbana no espaço intraurbano, agregaram-se nessa cartografia informações sobre as características urbanísticas do entorno dos domicílios urbanos, ${ }^{16}$ mapeando a presença de pelo menos duas redes de infraestrutura implantadas, como abastecimento de água via rede geral e presença de esgoto a céu aberto e abastecimento de água via rede geral e iluminação pública. Na cartografia 4, portanto, cada ponto representa 25 domicílios. Pode-se assim detectar áreas que, apesar de inseridas na área urbana, não contam com grau de urbanização completo, representadas no mapa por meio de pontos. ${ }^{17}$

A partir da sobreposição de dados referentes às redes de infraestrutura e reagrupamento dos setores, é possível chegar a uma leitura mais precisa do território, rompendo o padrão de território bipartido em urbano e rural. Salienta-se, contudo, que, como só foram coletados pelo IBGE dados do entorno de domicílios localizados em situação urbana, não foram coletadas informações da categoria 4 por estar fora da área urbana legal, apesar de abrigar regiões notórias por alto índice de áreas com urbanização incompleta, tais como loteamentos já habitados e localizados em áreas rurais, conjuntos habitacionais e núcleos desenvolvidos em torno de estabelecimentos industriais, comerciais ou de serviços.

Sabe-se que o IBGE faz a classificação dos setores censitários para 5.565 municípios antes da coleta dos dados. Esta análise aqui desenvolvida com os resultados das informações sobre as características do entorno não caminha no sentindo de demandar do IBGE uma reclassificação dos dados a posteriori da coleta. Apenas intenciona-se caminhar por meio de uma análise que estrutura o território além da dicotomia urbano-rural, utilizando-se do acesso a redes de infraestrutura urbana como um indicador que demonstra a inserção de uma dinâmica urbana, o acesso a redes de infraestrutura, em situações tidas conceitualmente como rurais, demonstrando a complexificação do espaço, como referida por Spósito (2013), sendo necessário superar a dicotomia. 


\section{O papel do IBGE para o planejamento intraurbano, urbano e regional}

Em primeiro lugar é importante disseminar a relevância das informações colhidas pelo IBGE sobre os locais de fato ocupados por população e com características urbanas dentro ou fora do perímetro municipal, dada a importância da informação demográfica e de condições de urbanização especializadas para uma cultura de planejamento territorial não só em metrópoles, mas nos 5.565 municípios brasileiros.

Há uma grave ausência da política pública do planejamento territorial municipal, atualmente com equipes e estruturas muito frágeis. A execução decenal do censo demográfico é um esforço técnico-operacional e financeiro nacional extremamente importante e, como engloba todos os municípios, apresenta-se como poderosa ferramenta para implementação de uma cultura de planejamento com base científica constante, com enormes avanços na evolução dos indicadores de sustentabilidade, condições e qualidade vida.

Não se pode deixar de mencionar que, muitas vezes, seus dados são, em muitos municípios, a única ferramenta existente. Por isso o Censo de 2020 já precisa ser pensado de forma integrada territorial e setorialmente. Sendo relevante este artigo pontuar a necessidade de integração entre a comunidade acadêmica, o IBGE e os municípios em iniciativas para elaborar as bases para um bom resultado no próximo censo. Um bom exemplo disso é a construção de bases nas quais os setores censitários sejam compatíveis com as unidades de planejamento municipal existente. Sabe-se da dificuldade de utilização de dados censitários devido à incompatibilidade entre limites censitários, bairros e faces de quadras, apesar dos esforços empreendidos pelo IBGE, no último censo, para atualização da base territorial municipal com representantes das municipalidades. Entretanto, diversos municípios não enviam informações atualizadas em tempo de construir uma base mais aprimorada para 0 próximo censo.

Diversos municípios brasileiros ${ }^{18}$ estão aprovando Lei de Abairramento, apoiados pelo IBGE, com a finalidade de melhorar o planejamento territorial e do orçamento, pois, tendo essa lei, o IBGE passa a utilizá-la para delimitação dos setores censitários municipais, tornando os dados estatísticos mais acessíveis ao planejamento municipal na escala do bairro. $A$ disseminação da Lei Municipal de Abairramento apresenta-se como instrumento importante para que dados produzidos pelo IBGE sejam disponibilizados para diagnóstico, planejamento e monitoramento dos resultados das políticas públicas municipais em escala adequada.

\section{Conclusões}

A respeito das principais potencialidades da utilização da variável "situação do setor" para estudos urbanos, destacamos que:

- a variável "situação do setor" a partir das oito classificações contribui no estudo da expansão urbana contemporânea quando utilizada de forma comparativa com dados de outros censos após 1991. Este estudo contribui para o mapeamento de situações como: a expansão do perímetro urbano; o crescimento das áreas urbanizadas contíguas a cidade ou vila; o crescimento de áreas urbanizadas de forma fragmentada; a expansão de aglomerados 
rurais; e a expansão de aglomerados de caráter urbano em área rural. Frisa-se, contudo, que este é um estudo complementar, realizado com o intuito de caracterizar, demograficamente ou a partir de aspectos socioeconômicos, as áreas de expansão urbana. Caso o intuito da pesquisa seja caracterizar o processo de expansão urbana, o mais indicado é pautar-se por imagens de satélite, para estudo do crescimento das áreas urbanizadas, e pela legislação urbanística quando o objetivo for mapear a expansão das áreas legalmente urbanas.

- A utilização das características do entorno urbanístico dos domicílios fornece informações espacializadas a respeito da qualidade das redes de infraestrutura nas áreas urbanas, possibilitando o cruzamento de variáveis do entorno urbanístico com características socioeconômicas e demográficas da população e do domicílio, podendo contribuir para a elaboração de políticas públicas municipais e metropolitanas.

- A variável "situação do setor" pode também ser utilizada a partir do reagrupamento de suas oito categorias de setores censitários, estruturando o território além da dicotomia urbano-rural. 0 espaço urbano pode ser representado pela classificação 1 - setores urbanos de cidade e vila; o espaço rural, pelo agrupamento das categorias 5, 6, 7, 8; e o espaço além dicotomia, pelas categorias 2, 3, e 4, respectivamente: área não urbanizada de vila ou cidade; área urbana isolada e área rural de extensão urbana. Apesar de esse tipo de mapeamento proporcionar uma leitura que rompe com o padrão de território bipartido entre urbano e rural, essa estruturação não deve ser utilizada de forma isolada, pois, igualmente, possui dados mascarados por trás de algumas das oito situações, como a categoria 1, que define uma área como urbana, mesmo quando não contemplada por redes de infraestrutura, caracterizando uma forma de urbanização incompleta.

A respeito das fragilidades, pode-se elencar algumas indicações de como superá-las, tais como:

- o IBGE poderia passar a disponibilizar, em seu banco de dados, informações quanto à fonte do perímetro urbano utilizada para fins censitários em cada município brasileiro, se legal ou se baseado na realidade instaurada, para os municípios que não possuem lei municipal de perímetro urbano.

- Faltam informações nas publicações do IBGE a respeito dos critérios utilizados para definição do que o órgão chama de "perímetro utilizado para fins de coleta censitária", necessário quando a municipalidade não conta com legislação referente ao perímetro urbano.

- De acordo com a forma definida pelo Instituto, mesmo que a administração municipal constate que a lei de perímetro não reflete a realidade municipal, enquanto este não aprovar alterações em sua legislação municipal, 0 IBGE continuará praticando os limites definidos em lei. Seria necessário estabelecer parâmetros quanto à participação da administração municipal na delimitação das áreas urbanas e rurais, mas fica claro que, pautar-se apenas em aspectos legais, deixando de lado demandas administrativas municipais, torna a coleta censitária aquém das reais possibilidades de utilização dos dados pelo planejamento municipal.

- Frisa-se que um território, mesmo dividido em oito categorias - muitas vezes abrangentes em sua caracterização, como a categoria 1, área urbana de cidade ou vila -, acaba tendo informações mascaradas. Citam-se, por exemplo, as informações quanto à presença 
de vazios urbanos, pois, apesar de a categoria 2 (área urbana não urbanizada) ter como objetivo mapear as áreas vazias inseridas em área urbana legal, as áreas não urbanizadas são constituídas apenas pelas áreas ocupadas por atividades agropastoris (lavouras, pecuária, atividades extrativas) e pelas terras ociosas (sem qualquer uso) quando não contíguas às áreas urbanas de cidade ou vila intensamente ocupadas com edificações, ruas e praças, etc.

- Quanto aos dados do entorno urbanístico dos domicílios, salienta-se que só foram coletados pelo IBGE dados do entorno de domicílios localizados na área urbana. É necessário incluir na coleta a categoria 4, que possui caráter urbano mesmo estando inserida em situação rural. Essa categoria, apesar de estar fora da área urbana legal, possui muitas vezes regiões notórias por alto índice de áreas com urbanização incompleta, tais como loteamentos já habitados e localizados em áreas rurais, conjuntos habitacionais, assentamentos precários e núcleos desenvolvidos em torno de estabelecimentos industriais, comerciais ou de serviços. Assim, o uso desses dados será mais efetivo para construção e avaliação de políticas públicas municipais e metropolitanas com a inclusão dessa categoria na coleta.

- Mostra-se frágil, igualmente, a inclusão das áreas de extensão urbana, categoria 4, como de situação rural - afinal, são espaços que também dialogam com a realidade urbana, sendo, portanto, áreas além da dicotomia urbano-rural.

Ao longo deste artigo foram pontuadas tanto as potencialidades quanto as fragilidades decorrentes do uso de dados oriundos do IBGE. Cabe relativizar que os limites dos dados muitas vezes se devem à impossibilidade de uma análise mais detalhada antes da coleta por parte do IBGE para os mais de 5 mil municípios brasileiros, bem como à incapacidade técnico-operacional de muitas gestões municipais e pesquisadores de utilizá-los. Não se pretendeu com este trabalho desqualificar as informações censitárias, mas sim pontuar a necessidade de os usuários das informações censitárias entrarem em contato com os limites e as potencialidades dos dados para sua utilização em pesquisas e para o planejamento territorial, sendo fundamental, para isso, conhecer igualmente o método utilizado pelo Instituto para coleta dos dados.

Ao serem apontadas potencialidades, caminha-se para a construção de indicadores mais complexos. $\mathrm{E}$, ao serem apontadas fragilidades, pretende-se apenas pontuar questões que podem, em algum momento, serem superadas, possibilitando um uso ainda mais intenso dos dados censitários em nosso País. 


\section{Mapa 4 - RMC - Reagrupamento dos setores e implantação de infraestrutura: água e esgoto}

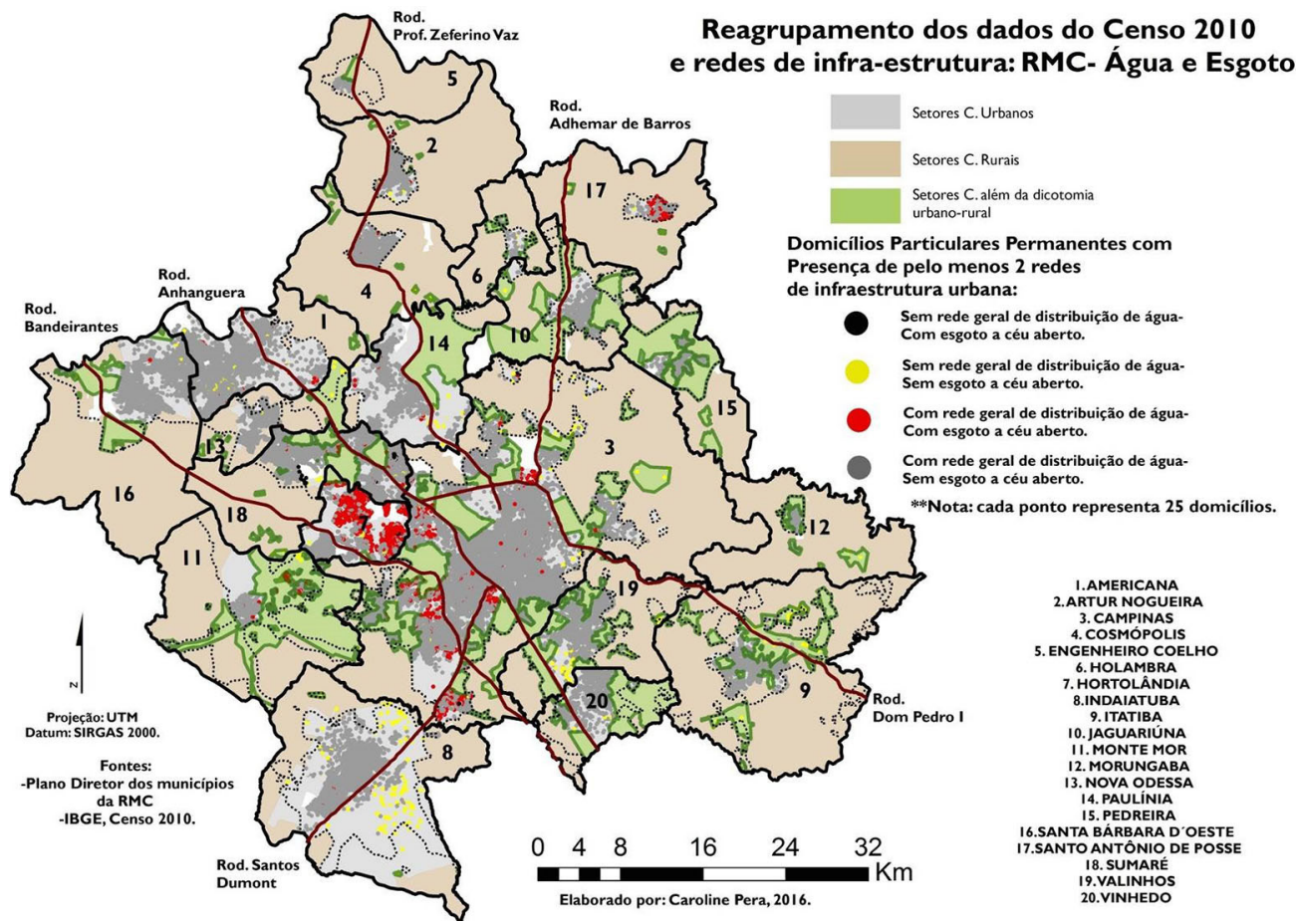

Fonte: IBGE (2010). Elaboração: Caroline Pera (2016).

\section{Caroline Krobath Luz Pera}

Pontifícia Universidade Católica de Campinas, Faculdade de Arquitetura e Urbanismo, Programa de Pós-Graduação em Urbanismo. Campinas, SP/Brasil.

carolinepera@gmail.com

\section{Laura Machado de Mello Bueno}

Pontifícia Universidade Católica de Campinas, aculdade de Arquitetura e Urbanismo, Programa de Pós-Graduação em Urbanismo. Campinas, SP/Brasil.

laurabueno500@gmail.com 


\section{Notas}

(1) Uma versão deste artigo foi apresentada durante o III Seminário Nacional do GT População, Espaço e Ambiente, da Abep, realizado na sede do IBGE no Rio de Janeiro. As autoras agradecem as contribuições dos participantes e do corpo técnico do IBGE, além da Capes e do CNPq pelo apoio a esta pesquisa.

(2) Conforme IBGE (2013, pp. 354-355), para os casos em que a administração local considere que a lei não reflete a realidade e enquanto não houver alteração da legislação, o IBGE continuará praticando os limites definidos em lei. Nos casos em que o perímetro urbano ultrapassa o limite municipal, o IBGE privilegia a legislação estadual sobre a legislação municipal. E, na ausência de lei definidora de perímetro urbano, o IBGE estabelece um perímetro urbano para fins estatísticos, como forma de definir as áreas urbanas e as rurais do município.

(3) Utilizou-se como estudo de caso a Região Metropolitana de Campinas (RMC), institucionalizada pela lei estadual n. 870/2000. A região apresenta hoje, após a recente inclusão de Morungaba, vinte membros: Americana, Artur Nogueira, Campinas, Cosmópolis, Engenheiro Coelho, Holambra, Hortolândia, Indaiatuba, Itatiba, Jaguariúna, Monte Mor, Morungaba, Nova Odessa, Paulínia, Pedreira, Santa Bárbara d’Oeste, Santo Antônio de Posse, Sumaré, Valinhos e Vinhedo.

(4) As áreas de apuração são "áreas geográficas delimitadas nos mapas e cadastradas para servir de unidade especial de apuração de dados censitários", como, por exemplo: os aglomerados rurais (os quatro tipos), as áreas urbanizadas, as áreas não urbanizadas, os aglomerados subnormais, as aldeias indígenas, etc. A identificação das áreas de apuração é um dos elementos que auxilia a elaboração do traçado dos setores censitários, havendo ainda outros elementos (IBGE, s/d). $\mathrm{Na}$ ausência de outras informações quanto ao método utilizado pelo IBGE, o conhecimento da informação a respeito da definição das áreas de apuração ajuda, em partes, a compreender a partir de quais critérios o IBGE trabalha. Mas vale frisar que seria fundamental que o IBGE passasse a detalhar tal informação em seus manuais e textos metodológicos.

(5) Essa classificação passou a ser aplicada pelo IBGE a partir do Censo de 1991. Antes, a variável "situação de setor" era dividida em apenas quatro situações: 1) cidade ou vila; 2) área urbana isolada; 3) aglomerado rural; e 4) zona rural.

(6) Para o Censo 2010, o tamanho estipulado para cada setor em áreas urbanas urbanizadas prevê de 250 a 400 domicílios; para os setores urbanos não urbanizados, o critério prevê de 150 a 250 domicílios ou de 100 a 200 estabelecimentos agropecuários. Quanto aos setores rurais, categorias 4, 5, 6, 7 e 8, o tamanho é, em média, de 200 domicílios ou 150 estabelecimentos agropecuários, admitindo-se faixa de variação de 150 a 250 domicílios e de 100 a 200 estabelecimentos agropecuários. Além disso: “[...] em área rural, o critério de tamanho está associado também à extensão territorial, além do quantitativo de estabelecimentos ou domicílios particulares, não sendo admitidos setores rurais cujas extensões territoriais fossem maiores que $500 \mathrm{~km}^{2}$ além do limite máximo de tempo de coleta ser de 60 dias" (IBGE, 2013).

(7) Segundo caracterização proposta pelo Censo 2010 (IBGE, s/d-c).

(8) Critério de tamanho e densidade, conforme citado na nota 6, comum a todos os tipos de aglomerados rurais. 
(9) “Definem-se, como aglomerado rural isolado, os assentamentos situados em área legalmente definida como rural, que atendam aos critérios de tamanho e densidade anteriormente estipulados e que se encontrem separados do perímetro urbano legal de uma cidade ou vila, ou de um aglomerado do tipo "extensão urbana" por uma distância igual ou superior a $1 \mathrm{~km}$ [...]. Os aglomerados isolados de natureza rural correspondem a formas de hábitat concentrado de população rural e, geralmente, reúnem um número mínimo de serviços que servem como elementos básicos de interação social." (IBGE, s/d-a, p. 14).

(10) Critério de tamanho e densidade, conforme citado na nota 6 , comum a todos os tipos de aglomerados rurais.

(11) Idem nota 9.

(12) Critério de tamanho e densidade, conforme citado na nota 6, comum a todos os tipos de aglomerados rurais.

(13) Idem nota 9.

(14) Critério de tamanho e densidade, conforme citado na nota 6, comum a todos os tipos de aglomerados rurais.

(15) Foram inseridas, no Quadro 2, todas as possibilidades de cruzamento, mesmo quando não encontradas no estudo de caso proposto, pois, além de caracterizar a Região Metropolitana de Campinas, pretende-se averiguar quais informações espaciais podem ser extraídas da espacialização da variável "situação do setor".

(16) O Censo 2010 apresentou, pela primeira vez, um perfil das características dos logradouros onde se localizam os domicílios urbanos do País, em nível municipal, abrangendo informações sobre presença de iluminação pública, pavimentação, arborização, bueiro/boca de lobo, lixo acumulado, esgoto a céu aberto, meio-fio ou guia, calçada e rampa para cadeirante no entorno dos domicílios considerados. Tais informações foram levantadas, em sua quase totalidade, durante a pré-coleta, etapa preparatória do Censo Demográfico 2010, e refletem a observação direta do agente censitário sobre o contexto urbanístico no que diz respeito a duas importantes dimensões de infraestrutura: a circulação e o meio ambiente. Disponível em: <http://biblioteca. ibge.gov.br/visualizacao/periodicos/96/cd_2010_entorno_domicilios.pdf>. Acesso em: set 2015.

(17) Cada ponto preto representa 25 domicílios, cujo entorno urbanístico não possui ambas as redes de infraestrutura. Cada ponto em cinza claro, ou em cinza escuro, representa 25 domicílios com pelo menos uma das redes de infraestrutura instalada. Os pontos em cinza médio representam 25 domicílios com ambas as redes de infraestrutura instauradas em seu entorno urbanístico, ou seja, situações que representam formas de urbanização completa. Há necessidade de transparência de informações sobre a desigualdade, de forma a que as políticas púbicas se voltem para enfrentar a equalização do acesso da população aos serviços urbanos. O IBGE tem um rico sistema de dados e suas ferramentas de georreferenciamento, além dos escolhidos, por serem relacionados a saúde pública e saneamento.

(18) Alguns dos municípios que aprovaram abairramento no estado de São Paulo são: Vinhedo, Barueri, Cubatão, Cajamar e Mongaguá. 


\section{Referências}

IBGE (s/d-a). XI Recenseamento geral do Brasil: Manual de delimitação dos setores de 2000. Vol. 22 Série Relatórios metodológicos. Rio de Janeiro.

(s/d-b). XI Recenseamento geral do Brasil - Manual de delimitação dos setores 2000.

(s/d-c). Banco Multidimensional de estatística. Disponível em: https://www.bme.ibge.gov.br. Rio de Janeiro. Acesso em: 12 set 2015.

(2002). Censo Demográfico 2000: agregado de Setores Censitários dos Resultados do Universo. Rio de Janeiro.

(2003). Metodologia do Censo Demográfico 2000. Vol. 25 da Série Relatórios metodológicos. Rio de Janeiro.

(2013). Metodologia do Censo Demográfico 2010. Vol. 41 da Série Relatórios metodológicos. Rio de Janeiro.

NASCIMENTO, E. (2013). As desigualdades socioespaciais urbanas numa metrópole interiorana: uma análise da RMC (SP) a partir de indicadores de exclusão social. Tese de Doutorado. Campinas, Universidade Estadual de Campinas.

PERA, C. K. L. (2016). Processo contemporâneo de expansão urbana: legislação urbanística e lógicas de produção do espaço urbano - Estudo da Região Metropolitana de Campinas. Dissertação de Mestrado. Campinas, Pontifícia Universidade Católica de Campinas.

SOUZA, M. L. de (2005). ABC do desenvolvimento urbano. Rio de Janeiro, Bertrand.

SPÓSITO, M. E. B. (2013). "A questão cidade-campo: perspectivas a partir da cidade". In: SPÓSITO, M. E. B. e WHITACKER, A. M. (orgs.). Cidade e campo: relações e contradições entre o urbano e o rural. São Paulo, Expressão Popular.

VEIGA. J. E. (2003). Cidades imaginárias: o Brasil é menos urbano do que se calcula. São Paulo, Autores Associados.

Texto recebido em 14/jan/2016

Texto aprovado em 31/mar/2016 